\title{
Enhancing Students' Speaking Skill through Gallery Walk Technique
}

\author{
Farrah Zakiyah Anwar \\ SMA Muhammadiyah (Plus) Salatiga \\ zakiyahfarrah@yahoo.com
}

\begin{abstract}
The aims of this research are (1) to describe the procedure of enhancing students" speaking skill by "gallery walk" technique at the first grade students of SMA Muhammadiyah (plus) Salatiga in academic year 2014/2015. (2) to find out whether the "gallery walk" technique can enhance students' speaking skill or not and (3) to find out the extent of the use of "gallery walk" technique enhancing students' speaking skill. The research method that is used in this research is classroom action reserach. The subjects of the research were 34 students in grade $X$ at SMA Muhammadiyah (plus) Salatiga. The researcher uses two cycles; each cycle consists of planning, action, observation and reflection. The result of this research shows that there is an enhancement of the students' speaking skill using "gallery walk" technique. It can be seen from T-Test calculating in cycle I is 5.09 and cycle II 6.70; T-Table with $\mathrm{N}=34$ is 2.035. And also the increasing students' mean score in percentage from cycle I to cycle II with the standardized score (the minimum of passing criteria) is 75 , At the cycle $\mathrm{I}$ is $55.88 \%$ students and $82.35 \%$ in the cycle II. The increasing of score in percentage from cycle I to cycle II is $26.47 \%$. This indicates that by applying "gallery walk" technique, the students' speaking skill can be enhanced.
\end{abstract}

Keywords: enhance, speaking skill, gallery walk technique. 


\section{Abstrak}

Tujuan dari penelitian ini adalah (1) untuk menguraikan bagaimana cara meningkatkan kemampuan berbicara siswa dengan tehnik gallery walk di kelas satu SMA Muhammadiyah (plus) Salatiga tahun ajaran 2014/2015. (2) untuk mengetahui apakah tehnik gallery walk mampu atau tidak meningkatkan kemampuan berbicara siswa, dan (3) untuk mengetahui peningkatan dari penggunaan tehnik gallery walk dalam meningkatkan kemampuan berbicara siswa. Metode penelitian yang digunakan adalah penelitian tindakan kelas. Subjek dari penelitian ini adalah 34 siswa di kelas X SMA Muhammadiyah (plus) Salatiga. Peneliti menggunakan dua siklus; setiap siklus terdiri dari perencanaan, tindakan, observasi dan refleksi. Hasil dari penelitian ini menunjukkan adanya peningkatan pada kemampuan berbicara siswa menggunakan tehnik gallery walk. Dapat dilihat dari perhitungan T-test di siklus pertama adalah 5.09 dan siklus kedua 6.70; T-table dengan $\mathrm{N}=34$ adalah 2.035. Serta peningkatan pada nilai rata-rata siswa dalam persentase dari siklus pertama dan kedua dengan nilai ketuntasan standar minimal adalah 75 , pada siklus pertama terdapat $55.88 \%$ siswa dan $82.35 \%$ pada siklus kedua. Peningkatan nilai dalam persentase dari siklus pertama sampai kedua adalah $26.47 \%$. Hal ini menyatakan bahwa dengan menerapkan tehnik gallery walk, kemampuan berbicara pada siswa berhasil ditingkatkan.

Kata Kunci: meningkatkan, kemampuan berbicara, tehnik gallery walk.

\section{Introduction}

In English language teaching, there are four skills included in: speaking, listening, reading and writing. Many people feel that speaking in a new language is harder than reading, writing or listening for two reasons. First, unlike reading or writing, speaking happens in real time. Usually the person, who we are talking to, is waiting for us to speak right then. Second, when we speak, we cannot edit and revise what we want to say, as we can do in writing.

Speaking in a foreign language involves a variety of processes, and learning to perform all of them quickly requires an extensive practice. 
However, speaking skill was observed as a difficult skill to be maintained. It was reflected from students' ability to communicate in English. The students tended to be silent in the classroom because they lack of selfconfidence. Students also need more practice since through practice students could learn to express their feeling, emotion, thought, and their intention. Besides, the teacher was not able to realize the students' problem in speaking and could not create a good situation in teaching learning process in the classroom.

Based on the observation when the writer taught in the classroom, there were many reasons that the students less in speaking. It may be caused by the students' shy or lack of self- confidence to speak in English. In previews, their study about English have not been maximally. They did not use English in daily life although in giving gratitude and meeting. Sometimes the students were less concentration when they have learning in the classroom. They were sleepy, not too understand about the material but shy to ask to the teacher, and unfamiliar with using dictionary. They considered that study English is difficult and not their daily language, so their study about English being not interested.

From the reason, the writer wants to enhance students' speaking skill by gallery walk technique. Gallery walk is one of the most versatile learner centered activities. The gallery walk connects learners to each other and learners to the training topic in a number of interesting, interactive ways (in Bowman, 2005: 1). By the use of gallery walk technique, the writerhopes the students are able to involve the emotional power to find a new knowledge and motivate them to be active to improve their self- confidence on English language especially in speaking skill. 


\section{Gallery Walk}

In Gallery walk is a presentation method in which individual learners or groups display their work products (often on posters) and then walk around the room viewing each other's work. They may be asked to provide feedback to the group of individual who created the work (Silberman, 1996: 24). From Silberman's statement means gallery walk allows students to be actively engaged as they walk throughout the classroom. They work together in small groups to share ideas and respond to meaningful questions, images, and problem-solving situations or texts.

In the other hand, Francek (2006: 27) describes that gallery walk is a discussion technique that gets students out of their chairs and into active engagement. The advantage of the method is its flexibility. A Gallery walk holds a variety of benefits for students and teachers alike.

The gallery walk is a powerful opening, closing, or review activity. In this activity, participants write on various pieces of chart paper that they have taped to the training room walls. Through a gallery walk, the students are able to learn from one another and from their own previous knowledge. The technique serves many different types of students' intelligences and many different ways in which students learn. It serves the kinesthetic learner, because it involves walking around and other movement, it serves the interpersonal learner, because it includes small group interaction, and it serves the verbal/linguistic learner, because it includes discussion and written answers.

Speaking is a skill which is often used for interaction with other. Majority of the people assess English through a speaking ability. However people fell worried to practice speaking ability because internal 
factors like motivation, lack of confidence and a low ability. As state by Chaney (1998: 13) which is quoted by Kayi (2006) "Speaking is the process of building and sharing meaning through the use of verbal and non-verbal symbols, in a variety of contexts". In addition, Speaking is an interactive process of constructing meaning that involves producing and receiving and processing information.

Besides that, Speaking is one of the important skills that have to be mastered by students in learning English. It is an essential tool for communicating. Talking about speaking is talking about communicating, express the ideas, feeling, opinions and others, that will be change for one person to another.

\section{Research Method}

The type of this research is Classroom Action Research (CAR). Classroom action research is research which is done by the teacher in teaching learning process to understand the situation and to improve the skill of the students in learning process. The classroom action research conducted in SMA Muhammadiyah (Plus) Salatiga which aims to enhance students' speaking skill through gallery walk technique.

The research was carried out in SMA Muhammadiyah (Plus) Salatiga. This school is located at J1. KH. Ahmad Dahlan No. 1 Soka, Salatiga. The place selection was based on the researcher have been teaching in a practical field experience program or PPL (Praktek Pengalaman Lapangan) and the institution has never conducted research about enhancing students' confidence in speaking skill through gallery walk technique.

The research was done at the second semester in the academic 
year of 2014/2015 and was conducted on May 2015. The subject of the research is the first grade students of SMA Muhammadiyah Plus Salatiga. The firts grade students consist of three classes, but the researcher took $\mathrm{X}$ IPA class. This class consists of 34 students, 10 male and 24 female. They come from high and middle economy families and most of them have high motivation to study.

\section{Discussion}

In the implementation of research, the researcher has arranged two cycles. The steps are: planning, acting, observing, and reflecting.

\section{Cycle I}

\section{Planning}

The teacher was preparing the materials, making lesson-plan, and designing the steps in doing the action; Preparing list of students' name and scoring; Determining teaching aids ( e.g. picture, board marker, carton, marker with a different colors, glue, digital camera, laptop; Preparing sheet of classroom observation; and determining test (pre-test and post-test).

\section{Action}

This research has been done on May 2015 in SMA Muhammadiyah (Plus) Salatiga on Wednesday, 06 ${ }^{\text {th }}$ May 2015. The research would be started on Saturday, 09 $9^{\text {th }}$ May 2015. At that time, the researcher and observer Sri Rejeki entered the class with the class condition was not too crowded. It seemed that they were ready to get the next lesson, so it do not need a long time to begin the class because the students have been already know about the researcher. 


\section{Observation}

In the first cycle, the researcher observed the learning process by asking the observer to help her in monitoring the students' activity and attention during the action in the classroom. This observation was purposed to know how far the early condition of students' skill in speaking, the situation of teaching learning process, also to collect the data. Before the researcher implemented the action, the students seemed nervous, had less confident and difficult to express their ideas. Largely they tended to be silent and answered the teacher's questions with bahasa. Actually the students had high motivation to learn English and understood to what the teachers said.

Table 1

The Students' Score of Pre Test and Post Test in Cycle 1

\begin{tabular}{|l|l|c|c|c|c|}
\hline No. & \multicolumn{1}{|c|}{ Name Of Students } & $\begin{array}{c}\text { Pre-test } \\
\text { I (X) }\end{array}$ & $\begin{array}{c}\text { Post } \\
\text { test } \\
\text { I (Y) }\end{array}$ & $\begin{array}{c}\text { Post-Pr } \\
\mathbf{e}(\mathbf{D})\end{array}$ & $\mathbf{D}^{\mathbf{2}}$ \\
\hline 1 & Abdul Rhohim & 60 & 60 & 0 & 0 \\
\hline 2 & Abdul Rohman & 56 & 60 & 4 & 16 \\
\hline 3 & Adinda Hakqi Pinandita & 64 & 76 & 12 & 144 \\
\hline 4 & Aditya Suwarsa & 76 & 80 & 4 & 16 \\
\hline 5 & Agus Hariyono & 60 & 64 & 4 & 16 \\
\hline 6 & Angga Setiawan & 64 & 76 & 12 & 144 \\
\hline 7 & Anggi Agustina & 68 & 76 & 8 & 64 \\
\hline 8 & Anita Sari & 64 & 68 & 4 & 16 \\
\hline 9 & Annisa Murti Solikhah & 68 & 76 & 8 & 64 \\
\hline 10 & Eka Puji Kusumaningrum & 60 & 68 & 8 & 64 \\
\hline 11 & Hafiz Hajar Nisyapuri & 56 & 60 & 4 & 16 \\
\hline 12 & Iin Zuliana & 56 & 60 & 4 & 16 \\
\hline 13 & Kodri & 80 & 80 & 0 & 0 \\
\hline
\end{tabular}




\begin{tabular}{|l|l|c|c|c|c|}
\hline 14 & Kusumastuti & 60 & 64 & 4 & 16 \\
\hline 15 & Laelatul Barokah & 76 & 76 & 0 & 0 \\
\hline 16 & Manis Sugiyanti & 72 & 76 & 4 & 16 \\
\hline 17 & Muhammad Rofiq & 72 & 68 & -4 & 16 \\
\hline 18 & Novita Sari Puji Astuti & 68 & 64 & -4 & 16 \\
\hline 19 & Nur Rohman & 60 & 64 & 4 & 16 \\
\hline 20 & Nuril Um Mayasari & 60 & 60 & 0 & 0 \\
\hline 21 & Nurma Yuliani & 80 & 84 & 4 & 16 \\
\hline 22 & Prihatiningsih & 76 & 76 & 0 & 0 \\
\hline 23 & Qonita Firdaus Jasareviq & 84 & 88 & 4 & 16 \\
\hline 24 & Ragil Monitasari & 68 & 64 & -4 & 16 \\
\hline 25 & Rizky Putri Nurjanah & 72 & 76 & 4 & 16 \\
\hline 26 & Sinta Cahyaningrum & 76 & 84 & 8 & 64 \\
\hline 27 & Sinta Larasati & 68 & 72 & 4 & 16 \\
\hline 28 & Slamet Lestari & 76 & 80 & 4 & 16 \\
\hline 29 & Sri Wahyu Sholekah & 76 & 76 & 0 & 0 \\
\hline 30 & Sutrisni & 68 & 76 & 8 & 64 \\
\hline 31 & Tiara Mafa Salsabila & 72 & 76 & 4 & 16 \\
\hline 32 & Yanuar Rista Putra & 64 & 64 & 0 & 0 \\
\hline 33 & Yesinta Kusuma Dewi & 80 & 80 & 0 & 0 \\
\hline 34 & Nasution & & & & \\
\hline Total & 76 & 80 & 4 & 16 \\
\hline
\end{tabular}

\section{Reflection}

After analyzing the result of the first meeting, There were 55.88\% students who passed the KKM (the minimum of passing criteria). The researcher and observer concluded that in the first cycle the mean of post test was higher than pre test. In this meeting, most of students felt bored with a method that usually used by the English teacher in the classroom. The result of post test showed that the students' speaking skill were good enough. The result of pre test was 68.70 , meanwhile in post- test 
was72.11. It was very important for the reseacher to continue the next cycle, to enhance the students' speaking skill with the same technique namely "Gallery walk". In the second meeting, a researcher hoped the students were more active to share their ideas to the class and speak confidently with friends.

\section{Cycle II}

\section{Planning}

The teacher was preparing the materials, making lesson-plan, and designing the steps in doing the action; Preparing list of students' name and scoring; Determining teaching aids ( e.g. picture, board marker, carton, marker with a different colors, glue, digital camera, laptop; Preparing sheet of classroom observation; and determining test (pre-test and post-test).

\section{Action}

On Monday, May $11^{\text {st }} 2015$ the researcher and observer Sri Rejeki entered the class by greeting and asking students' condition. She continued the lesson with the same material but different theme. In the second meeting, the researcher explained about gallery walk technique more detail in order to make sure that students have a fully understanding about it.

\section{Observation}

In cycle II, most of the students were more active in the learning process because they had already understood how to apply allery walk Technique.They practiced the dialog with confidence and they did not 
afraid to make mistakes because the researcher said to the students that mistakes were a process of learning. The students became enjoy with lesson without shy to ask something if they found difficulties. It was meant that the technique given by the researcher was successfully enhanced students' self- confidence in speaking skill.

\section{Table 2}

The Students' Score of Pre Test and Post Test in Cycle II

\begin{tabular}{|l|l|c|c|c|c|}
\hline No. & Name Of Students & $\begin{array}{c}\text { Pre-test } \\
\text { II (X) }\end{array}$ & $\begin{array}{c}\text { Post test } \\
\text { II (Y) }\end{array}$ & $\begin{array}{c}\text { Post-Pre } \\
\text { (D) }\end{array}$ & $\mathbf{D}^{2}$ \\
\hline 1 & Abdul Rhohim & 64 & 76 & 12 & 144 \\
\hline 2 & Abdul Rohman & 60 & 76 & 16 & 256 \\
\hline 3 & Adinda Hakqi Pinandita & 72 & 76 & 4 & 16 \\
\hline 4 & Aditya Suwarsa & 76 & 80 & 4 & 16 \\
\hline 5 & Agus Hariyono & 60 & 68 & 8 & 64 \\
\hline 6 & Angga Setiawan & 68 & 76 & 8 & 64 \\
\hline 7 & Anggi Agustina & 76 & 80 & 4 & 16 \\
\hline 8 & Anita Sari & 76 & 76 & 0 & 0 \\
\hline 9 & Annisa Murti Solikhah & 76 & 76 & 0 & 0 \\
\hline 10 & $\begin{array}{l}\text { Eka Puji } \\
\text { Kusumaningrum }\end{array}$ & 64 & 76 & 12 & 144 \\
\hline 11 & Hafiz Hajar Nisyapuri & 60 & 72 & 12 & 144 \\
\hline 12 & Iin Zuliana & 60 & 68 & 8 & 64 \\
\hline 13 & Kodri & 72 & 80 & 8 & 64 \\
\hline
\end{tabular}




\begin{tabular}{|l|l|c|c|c|c|}
\hline 14 & Kusumastuti & 60 & 76 & 16 & 256 \\
\hline 15 & Laelatul Barokah & 72 & 80 & 8 & 64 \\
\hline 16 & Manis Sugiyanti & 76 & 76 & 0 & 0 \\
\hline 17 & Muhammad Rofiq & 76 & 76 & 0 & 0 \\
\hline 18 & Novita Sari Puji Astuti & 64 & 68 & 4 & 16 \\
\hline 19 & Nur Rohman & 60 & 68 & 8 & 64 \\
\hline 20 & Nuril Um Mayasari & 64 & 68 & 4 & 16 \\
\hline 21 & Nurma Yuliani & 76 & 84 & 8 & 64 \\
\hline 22 & Prihatiningsih & 72 & 76 & 4 & 16 \\
\hline 23 & $\begin{array}{l}\text { Qonita Firdaus } \\
\text { Jasareviq }\end{array}$ & 80 & 92 & 12 & 144 \\
\hline 24 & Ragil Monitasari & 72 & 76 & 4 & 16 \\
\hline 25 & Rizky Putri Nurjanah & 76 & 80 & 4 & 16 \\
\hline 26 & Sinta Cahyaningrum & 76 & 80 & 4 & 16 \\
\hline 27 & Sinta Larasati & 76 & 76 & 0 & 0 \\
\hline 28 & Slamet Lestari & 76 & 80 & 4 & 16 \\
\hline 29 & Sri Wahyu Sholekah & 76 & 76 & 0 & 0 \\
\hline 30 & Sutrisni & 76 & 76 & 0 & 0 \\
\hline 31 & Tiara Mafa Salsabila & 76 & 76 & 0 & 0 \\
\hline 32 & Yanuar Rista Putra & 60 & 76 & 16 & 256 \\
\hline 33 & $\begin{array}{l}\text { Yesinta Kusuma Dewi } \\
\text { Total }\end{array}$ & 76 & 80 & 4 & 16 \\
\hline 34 & Zaidatus Sa'diyah & 76 & 76 & 0 & 0 \\
\hline
\end{tabular}




\section{Reflection}

The researcher concluded that there was an enhancement of students' speaking skill through gallery walk technique. It was proved by the result of score in cycle II. From the result of cycle I and II, the implementation of gallery walk technique enhances the students' speaking skill. Therefore, the more students' feel interest, the more students gain ability to speak in English.

\section{Table 3}

The Students' Mean Score in Percentage

\begin{tabular}{|c|c|c|}
\hline Category & Cycle 1 & Cycle 2 \\
\hline$<75$ & $4412 \%$ & $17.65 \%$ \\
\hline$>75$ & $55.88 \%$ & $82.35 \%$ \\
\hline
\end{tabular}

Table 4

The Mean of Students' Scores

\begin{tabular}{|c|c|c|c|}
\hline No & \multicolumn{1}{|c|}{ Analyze } & Cycle I & Cycle II \\
\hline$\bullet$ & $\begin{array}{r}\text { Mean } \\
\bullet \quad \text { Pretest }\end{array}$ & 68.70 & 70.59 \\
& $\bullet \quad$ Posttest & 72.11 & 76.35 \\
\hline$\bullet$ & T-Table N=34 & 2.035 & 2.035 \\
\hline$\bullet$ & T- Test calculation & 5.09 & 6.70 \\
\hline
\end{tabular}




\section{Conclusion}

The title of this research is 'Enhancing Students' Speaking Skill through Gallery walk Technique (A Classroom Action Research at the First Grade students of SMA Muhammadiyah (Plus) Salatiga in the Academic Year 2014/2015). The finding of the research in SMA Muhammadiyah (Plus) Salatiga shows:

The procedures of implementation of Gallery walk technique in enhancing students' speaking of the first grade students of SMA Muhammadiyah (Plus) Salatiga are as follows:

The teacher provides some materials needed such as: several sheets or carton, glue, different colored pens and discussion questions. The teacher divides the class into group with four or five students and gives each group a different colored pen. The students make their gallery in group and discuss what they have in the gallery. The teacher instructs each group to walk around to the next gallery. Every group has to review the task, discussion questions and any answer recorded by the previous groups. Then members of the group must add an informations or comments with a colored pen that represents their own group. After an appropriate amount of time (about 3 minutes), the students move to other gallery until all the groups have visited each gallery. The students return to their own gallery to prepare the comments and brief oral report to present in the larger class. This oral report as an opportunity for all the students to check their own understanding of the lesson. The teacher gives comments and summarizes the discussion questions in the end of learning.

The students' speaking skill can be enhanced by "gallery walk" 
technique in teaching learning process. It can be proved by the score of pre-test and post-test. The score of post-test are greater than pre-test. The cycle I shows that the score of pre-test is 68.70and the score of post-test is 72.11. Meanwhile, the cycle II shows that the score of pre-test is 70.59 and the score of post-test is 76.35 . It means that there is significant difference mean between pre-test and post-test. This indicates that "gallery walk" technique can enhance the students' speaking skill of the first grade students of SMA Muhammadiyah (Plus) Salatiga in the academic year 2014/2015.

The extent of using "Gallery walk" technique can be proved by t-test calculation. T-test is formula to know the significant differences between pretest and posttest. The t-test from this research is from 5.09 in the first cycle become 6.70 in the second cycle. From the t- test, it can be seen that there is enhancement from the first cycle to the second cycle. And also the increasing students' mean score in percentage from cycle I to cycle II with the standardized score (the minimum of passing criteria) is 75, At the cycle I is $55.88 \%$ students and $82.35 \%$ in the cycle II. The increasing of score in percentage from cycle I to cycle II is 26.47 $\%$.Furthermore, the gallery walk technique make the studentsmore enjoy because the atmosphere of the learning process not too formal. The students can express what they want to say and it can increase their skill in speaking to share their idea to the other friends in front of the class. 


\section{References}

Bowman, Sharon L. 2005. The Ten Minutes Trainer 150 Ways to Teach it

Quick and Make it Stick. San Fransisco: Pfeiffer.

Bowman, Sharon L. 2005. The Gallery Walk: An Opening, Closing, and Review Activity. [online] available:

http://www.boperson.com/BOWPERSON/GalleryWalk.pdf.

retrieved 18 November 2014.

Brown, H. Douglas. 2001. Teaching by Principle, an Interactive Approach to Language Pedagogy. Second Edition. New York: Longman.

Brown, H. Douglas. 2004. Language Assessment. New York: Longman.

Brown, H. Douglas. 2007. "Principles of Language Learning And Teaching fifth Edition”.'Unite State of America: Longman.

Burns, Anne. 2009. Doing Action Reserach in English Language Teaching. New York: Routledge.

Creswell, John W. 2012. Educational Research. University of Nebraska: Pearson.

Francek, Mark. 2006. Promoting Discussion in the Science Classroom Using Gallery Walks. Journal of College Science Teaching, September. Page 27-31 [online] available: http://blog.stetson.edu/jrseminars/wp-content/uploads/Gallery-Wal k.pdf retrieved 18 November 2014.

Harmer, Jeremy. 2001. “How to teach English”.England : Longman.

Kayi, Hayrine. 2006 Teaching Speaking: Activities to Promote Speaking in a Second Language. USA: TESL journal. [online] available: http://unr.edu/homepage/hayriyek retrieved 16 January 2015.

Shojaee. 1996. "Journal of As Effective Speaking Activity." 
Enhancing Students' Speaking Skill through Gallery Walk Technique

Silberman, Mel. 1996. Active learning: 101 Strategies to Teach Any Subject. U.K. A: Pearson Education Company.

Songsiri, Montha. 2007. An Action Research Study of Promoting Students' Confidence in Speaking Skill. Victoria University.

Taylor, P. 2001. Gallery Walk, http://www.cct.umb.edu/gallerywalk.html. retrieved 18 November 2014. 